\title{
Competitiveness of Textile and Apparel Industry of Bangladesh with China in In- ternational Trade
}

\author{
Hossain Md. Ekram ${ }^{1}$, Dechun Huang ${ }^{1}$, Quangdung Tran ${ }^{1}$ \\ ${ }^{1}$ Institute of Industrial Economics, Business School of Hohai University, Nanjing 210098, \\ China
}

\begin{abstract}
This paper used the Balassa Revealed Comparative Advantage (RCA) Index and the Spearman's Rank Correlation Coefficient $\left(r_{s}\right)$ to analyze the situation of competition and complementariness in the textile and apparel (T\&A) industry between Bangladesh and China in international trade. Data of eleven key products of the industry in 2000-2009 was analyzed. The study explored that in six of those eleven products competition exists and in five remaining products complementariness exists between Bangladesh and China in global market. Consequently, several solutions were proposed to help improve the competitiveness of Bangladeshi T\&A industry.
\end{abstract}

Key words: textile and apparel industry; competitiveness; international trade; Bangladesh; China

\section{Introduction}

The era of globalization since the late 1940s has dramatically changed the world's International trade patterns with the gradual reduction in trade barriers and more emphasis is now being placed on promoting export competitiveness [1] Competitiveness is an indicator of the ability to supply goods and services at the location and in the form and at the time sought after by buyers, at prices that are as good as or better than those of potential suppliers, while earning at least the opportunity cost of returns on resources employed ${ }^{[2]}$. In recent years; the importance of competitiveness has been increasingly recognized. Competitiveness can be evaluated at various levels; company, sector or industry and country ${ }^{[3]}$. Since the 1990s, China and Bangladesh have both made progresses in their foreign trade ${ }^{[4]}$. With the expansion of their trade volumes and overseas markets, the overlapping parts of their exporting products and markets have been being enlarged, which brought competition between the two nations ${ }^{[6]}$. China, after its accession into the World Trade Organization (WTO) in 2001, has been affecting Bangladesh's exports of T\&A goods in the international markets ${ }^{[5]}$. Some researchers investigated the competitiveness and complementariness in SinoBangladesh trade in T\&A and found there had been much resemblance in the exports of the two countries ${ }^{[6]}$. On January 1, 2005, the controlled trade regime on Textile and Apparel which was based on the Multi Fiber Agreement (MFA) was abolished ${ }^{[5]}$. This institutional change wrought great impacts on the world market for T\&A exports and Bangladeshi T\&A products have been facing greater competition with China in international markets ${ }^{[7]}$.

\section{Research Questions}

- How the competitiveness level of 
Bangladeshi T\&A industry in international trade with China is?

- How to improve the competitiveness of Bangladeshi T\&A industry in international trade with China?

\section{Objectives of the Research}

- Using the RCA index to analyze the situation of competitiveness of the T\&A industry of Bangladesh and China.

- Using the Spearman's Rank Correlation Coefficient $\left(r_{s}\right)$ index to analyze the relations of competition and complementariness in the T\&A industry between Bangladesh and China in international trade.

\section{Theoretical Background}

\subsection{Competitiveness and International Theories}

The concept of comparative advantage has been widely accepted as one of the foundations for international trade. A commonly used measure of industry specialization, based on export data, is revealed comparative advantage, often referred to as the Balassa Index (1965) ${ }^{[2]}$. The principle of comparative advantage is historically tied to the framework of the Ricardian trade model. In that framework the principle is unambiguous as long as only two products are involved. The extension to $\mathrm{n}$ products was first demonstrated by Dornbusch, Fischer and Samuelson (1977) and is now standard in most of the textbooks ${ }^{[3]}$. It is common in the empirical trade literature to measure comparative advantage by help of the Balassa index of 'revealed comparative advantage' (RCA). This measure reflects the success in exporting of countries relative to a world-wide norm.

\subsection{Bangladesh Economy and T\&A Industry}

Being the pillar industry, Banglad esh's T\&A export is now the $3^{\text {rd }}$ largest in the world ${ }^{[6]}$.This very dynamic sector has become the main source of direct and indirect employment, foreign exchange earnings, which in turn helped finance a growing share of imports of vitally important capital goods and essential inputs [9]. The export-oriented T\&A sector, with about 5150 firms and a workforce of directly 3.6 million and more than one million indirectly is a critical and important segment of the economy of Bangladesh. At present, more than 78 per cent of the country's export earnings come from T\&A and it contributes 40 per cent value addition to the manufacturing sector ${ }^{[10]}$.

\subsection{Chinese Economy and Textile and Apparel Industry}

Among all industries in China, T\&A industry is among the earliest sectors to begin the marketization, with strongest international competitiveness, fastest growth and most attention. At present, China has more than 100,000 T\&A manufacturers, and over 10 million people working in garment industry, among which more than $70 \%$ are skilled and technical workers and supports, directly or indirectly, around another 90 million people through its various backward and forward linkages ${ }^{[11]}$. The rapid and sustainable development of China's economy and the increasing consumption demand on apparel fuel the development of China's T\&A industry. Qualified labor power, the world's $30 \%$ raw materials, complete industry chain, favorable investment environment and continuous reform on related policies and facilities are the preconditions of the development of Chinese T\&A industry. Market-oriented reform has brought unprecedented vitality to Chinese T\&A industry and China has 
rapidly become the world's most dynamic apparel market ${ }^{[12]}$.

\subsection{Competition of Bangladeshi T\&A Industry with China in Major International Markets}

China is one of the major competitors for Bangladeshi T\&A export to the major international markets. From 2009 to 2011, US imports share (\%) of T\&A products from the world shows China is the major player and Bangladesh compete as the second largest supplier of T\&A after China and it shows a strong competition between the two countries to grab the US market ${ }^{[13]}$. As export earnings, USA is the largest market for Bangladeshi T\&A goods as a single country. Same like US market China is also the largest competitor in Canadian market ${ }^{[14]}$.On the other hand, EU market is a very crucial market for Bangladesh T\&A industry as more than $40 \%$ of total export of T\&A is to the EU market and Bangladesh enjoys some quota to export in EU market. In EU Market also China is the major player, where Bangladesh is the third major player in EU market after China and Turkey ${ }^{[15]}$. On other emerging Asian, African and South American markets, China is also the largest competitor for the T\&A industry export of Bangladesh.

\section{Research Methodologies}

After the review of academic literatures, the authors have selected two indices; The Balassa Revealed Comparative Advantage (RCA), and Spearman's Rank Correlation Coefficient $\left(r_{s}\right)$ to measure the competitiveness of T\&A industry of Bangladesh with China in International Trade. Among these two indices, the first one can illustrate the scope of the rivalry while the latter one explains its depth.11keyproducts;HS 52-Cotton, HS 53-Vegetable Textile Fibers, HS 54-Manmade Filaments, HS 55-Man-made Staple
Fibers, HS 56-Wadding Felt and Nonwoven Yearns, HS 58-Special Woven Fabrics, Tufted Textile Fibers, HS 59Impregnated Coated, Covered Laminated Textile, HS 60-Knitted Art of apparel and Clothing Accessories, HS 61-Knitted art of Apparel and Clothing Accessories, HS 62-Art of Apparel Clothing Accessories, and HS 63-Made up Textile articles have been chosen to analyze. To keep the completion and consistence of the data, "HS 1992" classification rule is adopted and the 2-Digits HS code is to be taken to make sort and comparison. Due to the availability of the data, this paper will select the data in2000-2009 and MS Excel software has been used to analyze the data.

The RCA, which measures a specific product's share in the country's total exports relative to a share of this product in the world trade, is to be used ${ }^{[1]}$.

$R C A_{i j}=\frac{x_{i j}^{i} d x_{w j}}{x_{i v} f x_{w}}$,

Where, $i=1,2 \ldots n, j=1,2 \ldots m$.

Here $R C A_{i j}$ is the revealed comparative advantage of country $i$ for Product $j . X_{i j}$ is export by country $\mathrm{i}$ of Product $j . X_{w j}$ is total amount of global exports of Product $j \cdot X_{i}$ is the total global exports of country $i$ and $X_{W}$ is total amount of global exports.

When $R C A_{i j}$ is more than 1 , it indicates economy $j$ has comparative advantage in product $\mathrm{i}$ in the world, and when $R C A_{i j}$ is less than 1 , it shows economy $j$ has no comparative advantage in product $\mathrm{i}$ in the world. To be specific, if $R C A_{i j}$ is more than 2.5 , this economy has very strong competitiveness in product $i$ in the world; if $R C A_{i j}$ is between 2.5 and 1.25 , this economy has strong competitiveness in product $i$ in the world; if $R C A_{i j}$ is between 1.25 and 0.8 , this economy has competitiveness in product $\mathrm{i}$ in the world; if $R C A_{i j}$ is less than 0.8 , this economy is competitively weak in product $i$ in the world ${ }^{[2]}$. 
With the RCA value of every single product, the Spearman's Rank Correlation Coefficient $\left(r_{s}\right)$ can be calculated to explain the thorough competitiveness or complementariness between the studied countries:

$r_{s}=1-6 \sum_{i=1}^{n} \frac{d_{i}^{2}}{n\left(n^{2}-1\right)} ;$

Where $\mathrm{d}_{\mathrm{i}}{ }^{2}=\left[\mathrm{RCA}(\mathrm{BD})_{\mathrm{i}}-\mathrm{RCA}(\mathrm{CN})_{\mathrm{i}}\right]^{2}$,

$\mathrm{RCA}(\mathrm{BD})$ and $\mathrm{RCA}(\mathrm{CN})$ are respectively Bangladesh's and China's RCA. Range of values: The value of $r_{s}$ is ranged from -1 to +1 . The positive mark shows that competition exists between the two nations and its degree increases with the increment of the value; while the negative one proves the complementariness relations and its degree rises with the elevation of the absolute value ${ }^{[8]}$.

To analyze the research questioners using the above two indices, secondary data have been collected from the database of The Asia-Pacific Research and Training Network on Trade.

\section{Result Analysis, Discussions and Recommendations}

Table 1: Analyzed Average RCA Value of Eleven Products (2000-2009)

\begin{tabular}{|c|c|c|}
\hline Country & Bangladesh & China \\
\hline $\begin{array}{l}\text { Very } \\
\text { Strong } \\
(>2.5)\end{array}$ & $\begin{array}{ll}\text { HS } & 53 \\
(100.124), H S & 61 \\
(27.929), H S & 62 \\
(27.64), \text { HS } & 63 \\
(12.196) & \end{array}$ & \begin{tabular}{|lr} 
HS 53 (2.56),HS & 60 \\
$(2.504)$, HS & 61 \\
$(3.271)$, HS & 62 \\
$(3.29)$, HS 63 & $(3.492)$
\end{tabular} \\
\hline $\begin{array}{l}\text { Strong } \\
(1.25-2.5)\end{array}$ & $\begin{array}{l}\text { HS } 56(1.586), \\
\text { HS } 58 \text { (1.297), }\end{array}$ & $\begin{array}{l}\text { HS } 52 \text { (2.11), HS } 54 \\
(1.531), \quad \text { HS } 55 \\
(1.75), H S 58(2.385)\end{array}$ \\
\hline $\begin{array}{l}\text { Medium } \\
(0.8-1.25)\end{array}$ & & $\begin{array}{l}\text { HS } 56(0.834) H S 59 \\
(1.023),\end{array}$ \\
\hline $\begin{array}{l}\text { Weak } \\
(<0.8)\end{array}$ & 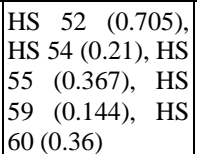 & \\
\hline
\end{tabular}

Based on the RCA index to analyze data of the eleven products of the Bang- ladeshi and Chinese T\&A industry, the result of competitiveness has been found as table 1. It shows that among the analyzed products, Bangladesh has very strong competitiveness in four products (HS 53, 61, 62, and 63) and has strong competitiveness in two products (HS 56 and 58) but has weak competitiveness infive products (HS 52, 54, 55, 59, and $60)$. This finding interprets that the competitiveness of Bangladeshi T\&A industry lies mainly in final products, which are mostly labor intensive products, rather than in the medium and raw products. In this regard, Bangladeshi T\&A industry should focus more on improving competitiveness upon the medium and "raw" products for the overall sustainability of the industry to compete in international trade. On the other hand for the Chinese T\&A industry, five out of eleven products have very strong competitiveness, four products have strong competitiveness, and two remaining products have medium competitiveness. This indicates that the Chinese T\&A industry should be viewed as one of the strongest competitors in international trade.

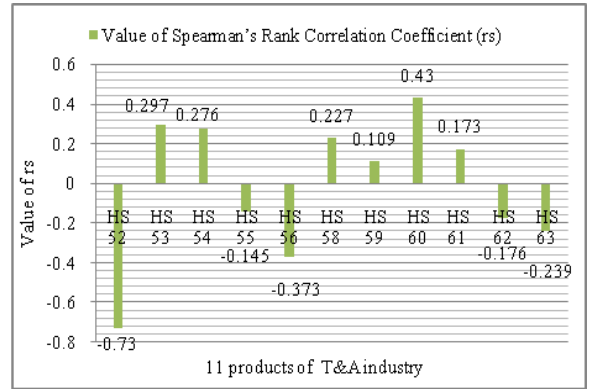

Figure 1- Average RCA (200-2009)

Figure 1 shows that there exist competition in six out of the eleven products (including HS 53, 54, 58, 59, 60, and 61) between China and Bangladesh. Further, HS 60, 53, and 54 were the three top ones which have the highest level of competitiveness. On the contrary, there exist 
complementariness in five remaining products (i.e. HS 52, 55, 56, 62, and 63) between these two countries in global trade. Among them, HS 52, 56, and 63 were the three top ones with the highest level of complementariness; especially the product of HS 52.

After combining the result of two indices, the authors give several solutions that improve the Bangladesh T\&A industry in international trade as table 2 .

Table 2: The results and improvement recommendations

\begin{tabular}{|l|l|}
\hline Products & Suggestions for Improvement \\
\hline $\begin{array}{l}\text { HS 52, HS 55 } \\
\text { (Bangladesh: Weak, } \\
\text { China: Strong, Sup- } \\
\text { port each other) }\end{array}$ & $\begin{array}{l}\text { Need special policies to improve } \\
\text { the trade relation in domain of } \\
\text { those products to gain more sup- } \\
\text { port from China in third market. }\end{array}$ \\
\hline $\begin{array}{l}\text { HS 56 (Bangladesh: } \\
\text { Strong, China: Me- } \\
\text { dium, Support each } \\
\text { other) }\end{array}$ & $\begin{array}{l}\text { Need policies to improve the } \\
\text { bilateral trade relation in the } \\
\text { product to support each other in } \\
\text { third market. }\end{array}$ \\
\hline $\begin{array}{l}\text { HS 62; HS 63 } \\
\text { (Bangladesh and } \\
\text { China: Very strong, } \\
\text { Support each other) }\end{array}$ & $\begin{array}{l}\text { Need special policies to improve } \\
\text { the trade relation with China in } \\
\text { domain of those products to sup- } \\
\text { port each other in third market }\end{array}$ \\
\hline $\begin{array}{l}\text { HS 58 (Bangladesh: } \\
\text { Strong, China: } \\
\text { Strong, Compete } \\
\text { each other) }\end{array}$ & $\begin{array}{l}\text { Find new markets; make more } \\
\text { cooperation and supporting poli- } \\
\text { cies with the new \& existing } \\
\text { markets. }\end{array}$ \\
\hline $\begin{array}{l}\text { HS 54, HS 60, HS } \\
\text { 59 (Bangladesh: } \\
\text { Weak, China: } \\
\text { Strong, Compete } \\
\text { each other) }\end{array}$ & $\begin{array}{l}\text { Find new markets; make policies } \\
\text { to improve itself in domain of } \\
\text { those products. Make more coop- } \\
\text { eration and supporting policies } \\
\text { with the new as well as present } \\
\text { markets. }\end{array}$ \\
\hline $\begin{array}{l}\text { HS 53; HS } \\
\text { 61(Bangladesh\& } \\
\text { China: Very strong, } \\
\text { Compete ) }\end{array}$ & $\begin{array}{l}\text { Find new markets; make more } \\
\text { cooperation and supporting poli- } \\
\text { cies with the new \& existing } \\
\text { markets. }\end{array}$ \\
\hline
\end{tabular}

And here are several additional suggestions by the related literature:

- Reducing the Lead time by way of setting up clusters, establishing affluent treatment facilities (particularly for knitwear-sector), and providing common facilities ${ }^{[7]}$.

- Image building and brand development ${ }^{[9]}$.

- Financial and technical support is needed to support and promote technological up-gradation for productivity enhancement of the T\&A sector in Bangladesh ${ }^{[13]}$.

- As with China and other prominent T\&A rivals, Bangladesh needs to address both the qualitative and quantitative expansion of her T\&A industry simultaneously in order to get product and market composition for the long run sustainability ${ }^{[15]}$.

- Seize Opportunities for Expanding Market Share in new markets ${ }^{[13,15]}$.

- Compliance with social and labor standards: international standard code, such as ISO or imported countries standard code [9]. Bangladesh will also need to strictly implement factory inspection and other regulatory measures to ensure that compliance requirements are strictly followed by the apparel enterprises ${ }^{[16]}$.

\section{Conclusions and Further Research}

This paper studied on competition and complementariness in the T\&A industry between Bangladesh and China. The findings found can be concluded by three main points as follows:

- Bangladesh and China competes each other in domain of products of HS53, HS 54, HS 58, HS 59, HS 60, and HS 61

- These two countries have complementariness each other in domain of products of HS 52, HS55, HS56, HS62, and HS63

- Several solutions, which are specific to each of those eleven products, were proposed.

This study has some limitations, which can also be viewed as directions 
for further research, such as data of only eleven leading products was used and data is not updated for 2010-2012.

\section{Acknowledgements}

The authors would like to express special thanks to China Scholarship Council and Industrial Economics Institute, Business School of Hohai University for their financial and institutional supports.

\section{References}

[1]. Vildan Serin \& Abdulkadir Civan, Revealed Comparative Advantage and Competitiveness: A Case Study for Turkey towards the EU, Journal of Economic and Social Research 10(2), 25-41, 2008

[2]. Asta Saboniene, Lithuanian Export Competitiveness: Comparison with other Baltic States, Engineering Economics, ISSN 1392-2785 (2). 2009

[3]. YUAN, Tao \& XU, Fu, China's Textile Industry International Competitive Advantage and Policy Suggestion, Journal of the Washington Institute of China Studies, Vol. 2, No. 1, p84-97, 2007

[4]. Jashim Uddin, Time Series Behavior of Imports and Exports of Bangladesh: Evidence from Co-integration Analysis and Error Correction Model, Journal of Economics and Finance, Vol.1, No.2, 2009

[5]. Tatsufumi Yamagata, Prospects of development of the garment industry in developing countries: What has happened since the MFA Phaseout? Institute of Developing Economies, JETRO, 2007

[6]. M. Abdur Rahaman, , Bangladesh Economy and Trade: Way Forward, EPB, DCCI Conference, 2008
[7]. Document of the World Bank, Bangladesh End of MFA Quotas, , No. 34964-BD, 2006

[8]. Yue Yunxia, China \& Mexico: Comparison of Trade Competitiveness, e Institute of Latin American Studies at the Chinese Academy of Social Sciences, Scholarly paper, 2007

[9]. Mustafizur Rahman and Asif Anwar, Bangladesh Apparels Export to the US Market: An Examination of Her Competitiveness vis-à-vis China, CPD, ISSN 1818-1597, 2006

[10]. Nazneen Ahmed, Bangladesh apparel industry and its workers in a changing world economy, Ph.D. thesis, Wageningen University-ISBN 90-8504-415-4, 2006

[11]. China Textile Network Company, Chinese Textile and Apparel Weekly, (CNTEX), accessed in 2012

[12]. Apparel Export Promotion Council (AEPC) of India, http://www.aepcindia.com accessed in 2012

[13]. Mohammed Ziaul Haider, Competitiveness of the Bangladesh Readymade Garment Industry in Major International Markets, Asia-Pacific Trade and Investment Review Vol. 3, No. 1, 2007

[14]. Ann Weston, Bangladesh's Access to the Canadian Market: Implications of the New Canadian LDC Initiative and Prospects for Export Diversification, Centre for Policy Dialogue, Paper Series-25, 2003

[15]. World Bank Report about Bangladesh, End of MFA Quotas: Bangladesh Must Act Quickly, 2006

[16]. MD. Arifur Rahman, Mir SohrabHossain, Compliance Practices in Garment Industries in Dhaka City, Journal of Business and Technology, Volume-V, Issue- 02, 2010 